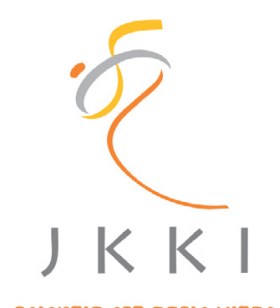

Jurnal Kedokteran dan Kesehatan Indonesia

Indonesian Journal of Medicine and Health

Journal homepage : www.journal.uii.ac.id/index.php/JKKI

\title{
Development of standardized herbal therapy of bangle extract (Zingiber Cassumunar Roxb.) on the expression of ICAM-1 for complementary therapy to prevent complications in malaria
}

Wiwien Sugih Utami*1, Heni Fatmawati ${ }^{1}$, Bagus Hermansyah ${ }^{1}$

${ }^{1}$ Medical Faculty of Jember University, Jember, East Java, Indonesia

Original Article

\begin{tabular}{|c|c|}
\hline & ABST \\
\hline ARTICLE INFO & Background: Malaria is still a major problem, both in international and \\
\hline $\begin{array}{l}\text { Keywords: } \\
\text { Zingiber cassumunar Roxb, } \\
\text { ICAM-1, } \\
\text { malaria, } \\
\text { immunostimulant, } \\
\text { complementary therapy }\end{array}$ & $\begin{array}{l}\text { release of Th1 (T helper-1) and release monocytes and macrophages to } \\
\text { perform phagocytosis and produce tumor necrosis factor-alpha (TNF- } \alpha \text { ). } \\
\text { The release of iNOS and free radicals would increase the expression of } \\
\text { adhesion molecules such as ICAM-1, VCAM-1, CD36, and P-selectin. } \\
\text { Research shows that IL- } 10 \text { can inhibit the production of TNF - } \alpha \text { and IL }\end{array}$ \\
\hline $\begin{array}{l}\text { *Corresponding author: } \\
\text { wiwien.dr@gmail.com }\end{array}$ & - 1. TNF- $\alpha$ and ICAM - 1 play a role in the occurrence of cerebral malaria. \\
\hline DOI : $10.20885 /$ JKKI.Vol8.Iss3.art8 & a complementary therapy to prevent the complications of malaria. \\
\hline $\begin{array}{l}\text { History: } \\
\text { Received: November 28, } 2016 \\
\text { Accepted: December 13, } 2017 \\
\text { Online: December 18, } 2017\end{array}$ & $\begin{array}{l}\text { Objective: This study aims to find the ability of Bangle (Zingiber } \\
\text { cassumunar Roxb.) extract as an immunostimulant which would be used } \\
\text { as a complementary therapy for standard malaria treatment. } \\
\text { Methods: A number of } 25 \text { mice Balb/C males were divided into } 5 \text { groups, } \\
\text { stimulated with methanol fractions of Bangle extract for } 14 \text { consecutive } \\
\text { days before infected with Plasmodium berghei. All groups were examined } \\
\text { for parasite daily, until day } 7 \text { post-positive malaria, referring to Artemisinin- } \\
\text { dose regimen administered orally } 0.04 \mathrm{mg} / \mathrm{g} \text { BW/day for } 7 \text { days. } \\
\text { Results : This study proves that the administration of Artemisinin } \\
\text { combined with methanol fraction of Bangle extract provides better results } \\
\text { to inhibit ICAM-1 gene expression in malaria-infected mice compared to } \\
\text { single-therapy Artemisinin or methanol fraction of bangle extract. } \\
\text { Conclusion: The combination of artemisinin and methanol fraction of } \\
\text { Bangle extract can inhibit ICAM-1 gene expression in malaria-infected } \\
\text { mice better compared to without the combination. }\end{array}$ \\
\hline
\end{tabular}

Latar Belakang: Malaria masih menjadi masalah utama dalam skala internasional dan nasional. Eritrosit yang mengandung Plasmodium sp. akan merangsang pelepasan Th1 (T helper-1) dan merangsang keluarnya monosit dan makrofag untuk melakukan fagositosis dan menghasilkan faktor nekrosis tumoralfa (TNF- $\alpha$ ). Pelepasan iNOS dan radikal bebas akan meningkatkan ekspresi molekul adhesi seperti ICAM1, VCAM-1, CD36, dan P-selectin. Penelitian sebelumnya menunjukkan bahwa IL-10 dapat menghambat produksi TNF- $\alpha$ dan IL-1. TNF- $\alpha$ dan ICAM-1 berperan dalam terjadinya malaria serebral. Bangle (Zingiber cassumunar Roxb.) diketahui memiliki potensi sebagai terapi komplemen dalam mencegah komplikasi malaria.

Tujuan: Tujuan dari penelitian ini adalah untuk mengetahui kemampuan ekstrak Bangle (Zingiber cassumunar Roxb.) sebagai imunostimulan yang digunakan sebagai terapi komplementer dalam pengobatan standar malaria. 
Metode: Sejumlah 25 ekor Balb/C jantan dibagi menjadi 5 kelompok, distimulasi dengan fraksi metanol ekstrak Bangle selama 14 hari berturutturut sebelum diinfeksi Plasmodium berghei. Semua kelompok diperiksa kadar parasit mereka setiap hari sampai hari ke 7 setelah malaria positif, yang mengacu pada rejimen dosis Artemisinin secara oral 0,04 mg/g bw /hari selama 7 hari.

Hasil: Penelitian ini membuktikan bahwa pemberian Artemisinin dikombinasikan dengan fraksi ekstrak Bangle methanolik memberikan hasil yang lebih baik untuk menghambat ekspresi gen ICAM-1 pada mencit yang menderita malaria dibandingkan dengan terapi tunggal Artemisinin atau fraksi ekstrak metanol bangle.

Kesimpulan: Kombinasi artemisinin dan fraksi ekstrak methanol Bangle menghambat ekspresi gen ICAM-1 pada mencit yang menderita malaria lebih baik dari pada tanpa kombinasi.

\section{INTRODUCTION}

Malaria is still considered as the main health concerned both internationaland national. World Health Organization (WHO) reported that there were 216 millions cases of malaria worldwide in 2010 and it was estimated that 655 thousand people died due to this disease. ${ }^{1}$ Malariacan still be found in every province in Indonesia, in which the highest malaria stratification (based on Annual Parasite Incidence/API) is in the Eastern part of Indonesia. The mortality rate (Crude Fatality Rate/ CFR) in all age groups had decreased from $2004(10,61 \%)$ to 2006 $(1,34 \%)$, however in $2006-2009$ it began to increase twice as high especially in the age group of 5-9 years old. ${ }^{2}$ The mortality of malaria is due to its complication, especially in Plasmodium falciparum infections that can develop into severe malaria. ${ }^{3}$

In severe malaria, there will be the overproduction of pro-inflammatory cytokine such as Tumour Necrosis Factor- $\alpha$ (TNF- $\alpha$ ), Interleukin-1 (IL-1), Interferon- $\gamma$ (IFN- $\gamma$ ) and free radicals such as Reactive Oxygen Intermediate (ROI), Reactive Oxygen Species (ROS), Nitric Oxide (NO) by phagocytic cells and activated endothelial cells. The production of these mediators is originally aimed to terminate the parasites, however, due to the unspecified-nature of free radicals, it can also damage the surrounding cells. ${ }^{4}$ Study had shown a high concentration of serum TNF- $\alpha$ which correlate to the progressivity of cerebral malaria. ${ }^{5}$ The results of average TNF- $\alpha$ concentration measurements showed that the TNF- $\alpha$ concentration in complicated malaria was higher than those without complication. TNF- $\alpha$ alone should not be used as the only parameter, the response of regulatory or anti-inflammatory cytokines should also be perfomed. The high characteristic ratio of TNF/ IL-10 in patients with cerebral malaria showed that the production of IL-10 was inadequate to prevent or combat erythropoiesis inhibition and erythrophagocytosis increase induced by TNF, and or decrease pro-inflammatory stimuli. The balance between cytokines produced by Th1, for instance, TNF- $\alpha$ and IFN-y, as well as cytokines produced by Th2, for instance, IL-4 and IL-10, could possibly determine the severity of malaria falciparum. An in vitro experiment, using the cells of malaria patients, showed that IL-10 could inhibit the production of TNF- $\alpha$ and IL-1. In this study, it was found that in malaria caused by Plasmodium falciparum, the concentration of IL-12 and IL-10 would increase. ${ }^{4}$

The interaction between p-RBC and endothelial cells is made possible by the presence of various receptors, such as ICAM-1, VCAM1, CD-36, and thrombospondin. ${ }^{6}$ The paste of p-RBCon endothelial cells by ICAM-1, especially in vital organs, will possibly cause a severe illness or death. ${ }^{5}$ If p-RBC pasted on brain venules, a severe complication could occur, such as cerebral malaria. $^{7}$

Bangle (Zingiber cassumunar Roxb.) is an herb that originated from the same family as tumeric (Curcuma sp.). It contains 42 components, such as sabinen, terpinen-4-ol, sesquifeladren, sineol, acids andgoms, organic acids and albuminoid, as well as curcuminoid (casumin A, B, C). ${ }^{8}$ The active ingredients of Bangle had a immunostimulant effects. Curcumin, for instance, had been proven as an immunomodulator which could increase the expression of CD 36 in monocyte and macrophage that has a vital role in mediating non-opsonized phagocytosis. ${ }^{6}$ 
Thus, the administration of adjuvant therapy accompanying standard malaria regiments might be an effective treatment course for severe malaria.

This study aims to determine the capability of Bangle (Zingiber cassumunar Roxb.) extract as an immunostimulant in malaria through the assessment of ICAM-1 serum gene expression, and then to develop Bangle extract as a standardized herbal medicine in malaria complementary treatment.

\section{METHODS}

This study was a laboratory experimental research with a Pretest and posttest controlled design. Study subjects were $25 \mathrm{Balb} / \mathrm{C}$ mice, weighing 20-30g and between the age of 2-3 months old. Subjects were divided into 5 groups induced with Plasmodium berghei strain ANKA and treated with standardized Artemisinin, and later the immunomodulation effect was assessed by observing the ICAM-1 gene expression. Ethical clearance had been obtained from the Ethical Committee of Medical Faculty Universitas Jember with certificate number 623/H25.1.11/KE/2015.

Before being used in this experiment, the methanol fraction of Bangle extract was standardized by measuring its curcumin concentration using TLC-densitometry method. ${ }^{9}$ The results of Bangle (Zingiber cassumunar Roxb.) extract standardization process, based on its organoleptic structure, was semi-solid, dark brown in color, with a strong unique scent, and thick consistency. The Total Chemical Content Concentration of Bangle extract was 33,2 mg curcumin in 1 gram of Bangle extract with ethanol $96 \%$ solvent.

Rat models were adapted for 1 week in the laboratory, fed with feed, and then given drinks with the solution of methanol fraction of Bangle extract for 14 days straight to stimulate the immune response of the rat models. After that, they were infected with Plasmodium berghei. After they were tested positive for malaria infection, they were treated with Artemisinin 0,0364 mg/kg BW. In K-IV and K-V, Bangle extract was still given until the end of the artemisinin treatment. The treatment period was 7 days, referring to the dosage regiment of Artemisinin $0,04 \mathrm{mg} / \mathrm{g} \mathrm{BW} /$ days for 7 days. ${ }^{10}$ During the 7 days of intervention, the level of parasitemia was observed through a blood vessel in the tails. After intervention had finished, rat modes were anesthetized and its spleen was taken to examine ICAM-1 gene expression.

The examination of ICAM-1 gene expression was done by isolating the RNA from the spleen using RNA isolation kit. Next reverse transcriptase-PCR was done to obtain cDNA. PCR used ICAM-1 specific primer, then electrophoresis was done. The data from DNA bands were processed using Image Analyzer. The end results were the illustration of ICAM-1 gene expression in semiquantitative form. Data analysis included descriptive and inferential statistical analysis. Statistical analysis was done with SPSS for Windows.

\section{RESULTS}

The results from PCR amplification was run through electrophoresis using agarose gel, then the gel band analysis of the results of electrophoresis was done using ImageJ analyzer software by measuring the quantity of the band thickness. Conventional PCR can be used to obtain quantitative data by using competitor (internal exogenous standard) or housekeeping gene (internal endogenous standard). Housekeeping gene as a reference gene utilized here was GAPDH (Glyceraldehyde-3-Phosphate Dehydrogenase) with $165 \mathrm{bp}$ measurement.

The high rendementin the methanol solvent showed that this solvent could extract more bioactive component with higher polarity. This happened because methanol has a stronger polar group than the nonpolar group, it can be seen from its chemical structure, in which methanol has hydroxylgroups (polar) and carbonyl groups (nonpolar), thus methanol had higher curcumin content and its effect was also larger in the rat models with the same dosage. ${ }^{11}$ 




Figure 1.The results of PCR DNA ICAM-1 (101 bp) for every intervention groups Figure notes:

1 : normal rat models, without malaria

2 : stimulated rat modes, infected with malaria but no treatment (negative control)

3 : stimulated rat models, infected with malaria and treated with Artemisinin 0,0364mg / mg BW/day(positive control)

4 : stimulated rat models, infected with malaria and treated with Bangle + Artemisinin $0,0364 \mathrm{mg} / \mathrm{mg} \mathrm{BW} /$ day

5 : stimulated rat models, infected with malaria and treated with Bangle only

The high rendementin the methanol solvent showed that this solvent could extract more bioactive component with higher polarity. This happened because methanol has a stronger polar group than the nonpolar group, it can be seen from its chemical structure, in which methanol has hydroxylgroups (polar) and carbonyl groups (nonpolar), thus methanol had higher curcumin content and its effect was also larger in the rat models with the same dosage. ${ }^{11}$

The results of parasitemia measurements showed that the group who was intervened with bangle and artemisinin had the lowest parasitemia level (Group IV). All groups were given immunomodulation from the methanol fraction of Bangle extract $0,045 \mathrm{mg} / \mathrm{kgBW} /$ day except for group I. The highest parasitemia level was found in the negative control group (no intervention), while the positive control group, who was intervened with Artemisinin only (Group III), showed higher parasitemia level than group IV. The group that was treated with Bangle extract only showed a lower parasitemia level than the negative control group.

The result of data analysis of ICAM-1 using Oneway ANOVA parametric test showed $p$ value $=0,149$. $P$ value $>\alpha$, where $\alpha=0,05$, which means that there is no significant difference among the groups. LSD analysis test showed that there was statistically significant difference between group II with group IV and group V, and vice versa, however the association was insignificant when compared to group I and III. Group I and II was also had no statistically significant difference with group II, group IV or VII, group IV or group V. 


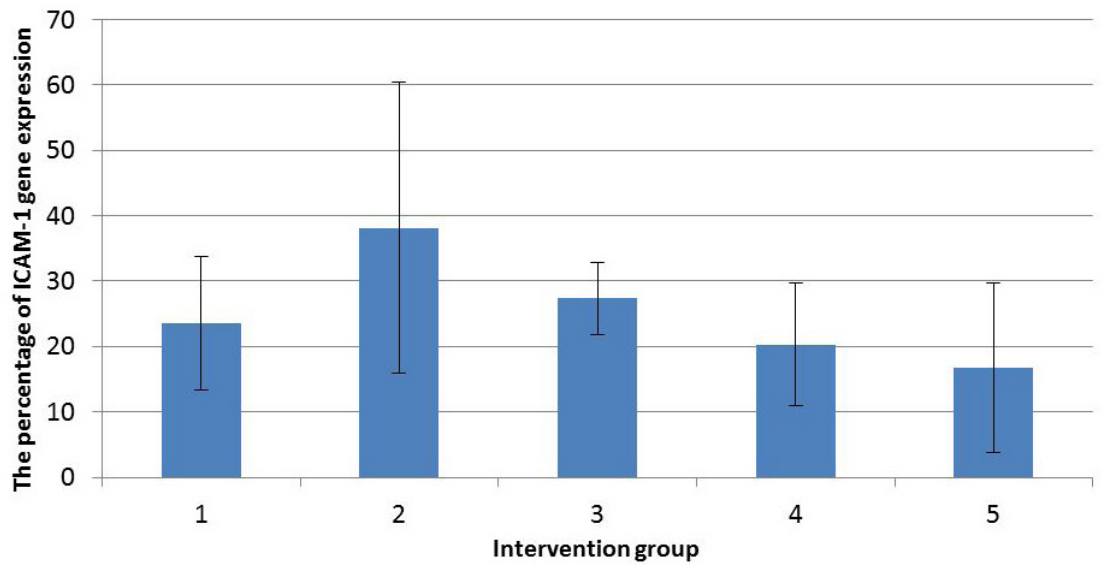

Figure 2. The percentage of ICAM-1 gene expression Graphic notes:

1 : Normal rat models, no malaria infection

2: Stimulated rat models, infected with malaria but no treatment (negative control)

3 : Stimulated rat models, infected with malaria and treated with Artemisinin 0,0364mg / mg BW/day (positive control)

4 : stimulated rat models, infected with malaria and treated with Bangle + Artemisinin 0,0364mg/mg BW / day

5 : stimulated rat models, infected with malaria and treated with Bangle only

\section{DISCUSSION}

The balance between cytokines produced by Th1, like TNF- $\alpha$ and IFN-Y, as well as cytokines produced by Th2, like IL-4 and IL10 , could determine the severity of malaria falciparum. Immune response against malaria, especially those involving cytokines, should be well-regulated because it could determine the mortality of patients with severe malaria. TNF- $\alpha$ is a main pro-inflammatory cytokine in innate immunity that contributes to tissue or organ damage when produced in high concentration. IFN- $\gamma$, another pro-inflammatory cytokine which activates macrophage and has a vital role in innate and adaptive immunity against intracellular microbes (including Plasmodium), is thought to have a central role in regulating the immune response against malaria because it activates the macrophage to produce TNF- $\alpha$ and IL-10. These cytokines are local and systemic inflammatory mediator, and they can be produced in high concentration hence they are easy to be detected in serum. ${ }^{12}$ During an increase and decrease of pro-inflammatory and anti-inflammatory cytokines, the absolute concentration of pro-inflammatory and antiinflammatory cytokines, the balance of proinflammatory and anti-inflammatory cytokines will affect the clinical manifestation of severe malaria. According to these explanations, proinflammatory and anti-inflammatory cytokines can assist parasite elimination, however, they can also initiate pathological changes in severe malaria.

Based on this study, there is significant difference of ICAM-1 gene expression between the groups who were treated with standard artemisin therapy combined with Bangle extract and those who were not given any treatment and only given Bangle extract alone. Combination therapy also generated better results when compared to single artemisin therapy (however the difference was insignificant).

ICAM-1 expressions contribute in cytoadherence and rosetting in malaria infections. Cytoadherenceand rosetting could 
obstruct blood vessels/ venules which would damage the organs. ICAM-1 expression in endothelial cells would increase with the presence of pro-inflammatory cytokines, such as tumor necrosis factor- $\alpha$ (TNF- $\alpha$ ), interleukin-1 (IL-1), and interferon- $\gamma($ IFN- $\gamma){ }^{13}$

In the treatment of Bangle extract, the effects of pro-inflammatory cytokines would be inhibited by the anti-inflammatory properties owned by the Curcumin content of Bangle extract. The inhibition of TNF- $\alpha$, IL-1, and IFN- $\gamma$, would decrease ICAM-1 gene expression. Curcumin content could decrease the concentration of INF $\gamma$ and significantly increase IL-10, thus the antibodies against malaria would be massively produced. The administration of Bangle fraction could stimulate the production of immunomodulator, which in turn would increase IL-10 antibodies. Thus, the administration of Bangle fraction as an adjuvant therapy for Artemisinin could prevent the complications of malaria, one of which is Cerebral malaria. In anotherword, the administration of artemisininwould eradicate the parasites, while Bangle extract would stimulate the production of antibodies as a protection against the parasites. This statement is supported by a previous study, in which the pathogenesis of cerebral malaria is thought to derive from an increase of pro-inflammatory cytokine production with an increase of endothelial adhesion molecular regulation. Curcumin has an antiinflammatory activity and therapeutic effects in cerebral malaria, by inhibiting the activities of NF-kB, followed by a down-regulation of proinflammatory cytokine production and molecular cytoadhesion expression in endothelial cells. ${ }^{14}$

The administration of methanol fraction of Bangle extract in Group IV and V could suppress ICAM-1 gene expression. In Group II (negative control), ICAM-1 gene expression was very high because no treatment was administered. This happened because the ICAM-1 receptor would be present constantly in leukocyte and endothelial cell membrane, even in low concentration. ${ }^{13}$

\section{CONCLUSION}

Based on the results of this study, the administration of Artemisinin combined with the methanol fraction of Bangle extract is able to inhibit ICAM-1 gene expression in Plasmodiumberghei ANKA- infected Balb/C rat models significantly and generate better results when compared to the administration of Artemisinin or Bangle extract alone. This means that the methanol fraction of Bangle extract can be used as a proper option for complementary therapy in malaria.

\section{REFERENCES}

1. World Health Organization. Malaria [Internet]. World Health Organization Publication. 2013 [cited 2013 Sep 14]. Available from: http://www.who.int/mediacentre/ factsheets/fs094/en/

2. Pusat Data dan Informasi DP, Penyakit Bersumber Binatang. Epidemiologi malaria di Indonesia. Buletin Jendela Data dan Informasi Kesehat. 2011;1:1-16.

3. Kun JF, Klabunde J, Lell B, Luckner D, Alpers M, May J, et al. Association of the ICAM-1Kilifi mutation with protection against severe malaria in Lambaréné, Gabon. The American Journal of Tropical Medicine and Hygiene. 1999;61(5):776-9.

4. Boeuf PS, Loizon S, Awandare GA, Ka Tetteh J, Addae MM, Adjei GO, et al. Insights into deregulated TNF and IL-10 production in malaria: implications for understanding severe malarial anaemia. Malaria Journal. 2012;11(253):1-9.

5. Grau G, Fajardo L, Piguet P, Allet B, Lambert P, Vassalli P. Tumor necrosis factor (cachectin) as an essential mediator in murine cerebral malaria. Science (80-). 1987;237(4819):1210-2.

6. Bamwell JW, Asch AS, Nachman RL, Yamaya M, Aikawa M, Ingravallo P. A Human 88-kD membrane glycoprotein (CD36) functions in vitro as a receptor for a cytoadherence ligand on Plasmodium falciparum-infected erythrocytes. The Journal of Clinical Investigation. 1989;84(3):765-72.

7. Fry AE, Auburn S, Diakite M, Green A, Rich- 
ardson A, Wilson J, et al. Variation in the ICAM-1 gene is not associated with severe malaria phenotypes. Genes and Immunity. 2008;9(5):462-9.

8. Astuti TB. Uji aktivitas antimikroba ekstrak etanol 70\% rimpang Bangle (Zingiber purpureum Roxb.) terhadap bakteri Staphylococcus aureus ATCC 25925 dan jamur Microsporum canis secara in vitro. 2013. (Institutional Repository of UIN Syarif Hidayatullah Jakarta).

9. Armiyanti Y, Utami WS, Ameliana L, Terlibat M, Risqi, Rahmawati M, et al. Pengembangan ekstrak rimpang Bangle (Zingiber Cassumunar Roxb.) terstandar menjadi granul efervesen sebagai terapi ajuvan untuk mencegah komplikasi pada malaria. 2013. (Institutional Repository of Universitas Jember).

10. Fitri LE, Rosyidah H, Sari NP, Endarti AT. Effect of N-Acetyl Cysteine administration to the degree of parasitemia and plasma interleukin-12 level of mice infected with Plasmodium berghei and treated with artemisinin. Medical Journal of Indonesia. 2009;18(1):5-9.

11. Jeenapongsa R, Yoovathaworn K, Sriwatanakul KM, Pongprayoon U, Sriwatanakul K. Anti-inflammatory activity of (E)-1-(3,4-dimethoxyphenyl) butadiene from Zingiber cassumunar Roxb. Journal of Ethnopharmacology. 2003;87(2-3):143-8.

12. Hunt NH, Golenser J, Chan-Ling T, Parekh S, Rae C, Potter S, et al. Immunopathogenesis of cerebral malaria. International Journal for Parasitology. 2006;36(5):569-82.

13. Ho M, White NJ. Molecular mechanisms of cytoadherence in malaria. American Physiological Society. 1999;276(6 Pt 1):C123142.

14. Padmanaban G, Arun Nagaraj V, Rangarajan PN. Artemisinin-based combination with curcumin adds a new dimension to malaria therapy. Current Science. 2012;102(5):704-11. 